\title{
PENGARUH SUHU PENYIMPANAN TERHADAP KADAR TABLET VITAMIN C YANG DIUKUR MENGGUNAKAN METODE SPEKTROFOTOMETRI $U V$-VIS
}

\author{
(THE EFFECT OF STORAGE TEMPERATURE ON THE CONCENTRATION OF \\ VITAMIN C TABLET WERE MEASURED USING $U V$-VIS SPECTROPHOTOMETRY)
}

\author{
PUTU ERA SANDHI KUSUMA YUDA, NI MADE DHARMA SHANTINI SUENA* \\ *Akademi Farmasi Saraswati Denpasar, Jalan Kamboja No 11A, Denpasar, Bali
}

\begin{abstract}
Abstrak: Mutu suatu obat atau kualitas produk sangat penting karena akan menentukan efek terapetik. Penyimpanan obat yang kurang baik merupakan salah satu masalah yang dapat mengganggu dalam upaya mempertahankan mutu obat. Vitamin $\mathrm{C}$ merupakan salah satu vitamin yang mudah rusak. Karena vitamin $\mathrm{C}$ mudah teroksidasi pada suhu tinggi dan dipercepat oleh panas, sinar, alkali, enzim, oksidator, serta oleh katalis tembaga dan besi. Oksidasi akan terhambat apabila vitamin $\mathrm{C}$ dibiarkan dalam keadaan asam, atau pada suhu rendah. Salah satu sediaan yang sering di konsumsi adalah vitamin $\mathrm{C}$ dalam bentuk tablet. Penelitian ini dilakukan untuk mengetahui pengaruh suhu penyimpanan terhadap kandungan vitamin $\mathrm{C}$ pada tablet yang dijual di pasaran. Pada penelitian ini digunakan dua macam sampel tablet vitamin $\mathrm{C}$ yang diperoleh secara acak (random sampling) dari apotek $\mathrm{X}$ yang berada di daerah Denpasar. Sampel diberi perlakuan berupa penyimpanan pada suhu dingin $\left(5^{\circ} \mathrm{C}\right)$, suhu kamar $\left(27^{\circ} \mathrm{C}\right)$ dan suhu panas berlebih $\left(48^{\circ} \mathrm{C}\right)$ selama 180 menit dengan tiga kali pengulangan dan kadar vitamin $\mathrm{C}$ diukur menggunakan metode spektrofotometri UV-Vis. Kandungan tablet vitamin $\mathrm{C}$ tertinggi ditemukan pada tablet yang disimpan pada suhu dingin $\left(5^{\circ} \mathrm{C}\right)$ dengan persentase kadar sampel $\mathrm{I}=100,6 \%$ dan sampel $\mathrm{II}=101,3 \%$. Kandungan vitamin $\mathrm{C}$ terendah terdapat pada tablet yang disimpan pada suhu panas berlebih $\left(48^{\circ} \mathrm{C}\right)$ dengan persentase kadar sampel I $=91,2 \%$ dan sampel II $=96,6 \%$. Dari hasil uji statistik didapat hasil tidak ada perbedaan yang bermakna dari sampel I dan II yang disimpan pada suhu dingin $\left(5^{\circ} \mathrm{C}\right)$ dengan suhu kamar $\left(27^{\circ} \mathrm{C}\right)$. Sedangkan terdapat perbedaan yang signifikan pada tablet yang disimpan pada suhu panas berlebih $\left(48^{\circ} \mathrm{C}\right)$. Berdasarkan penelitian yang telah dilakukan dapat disimpulkan bahwa suhu penyimpanan berpengaruh terhadap kandungan tablet vitamin $\mathrm{C}$, dimana penyimpanan pada suhu berlebih dapat menurunkan kadar vitamin $\mathrm{C}$ pada tablet.
\end{abstract}

Kata Kunci: Tablet Vitamin C, Kadar Vitamin C, Pengaruh Suhu Penyimpanan, Spektrofotometri UV-Vis.

\begin{abstract}
The quality of a drug or product quality is very important because it will determine the therapeutic effect. Poor storage of drugs is one of the issues that could interfere with the effort to maintain the quality of medicines. Vitamin $\mathrm{C}$ is one of vitamin that is easily damaged. Because vitamin $\mathrm{C}$ is easily oxidized at high temperatures and accelerated by heat, light, alkali, enzymes, oxidizing agents, as well as by the copper and iron catalysts. Oxidation is inhibited when vitamin $\mathrm{C}$ is left in a state of acid, or at low temperatures. One preparation that is often in the consumption of vitamin $\mathrm{C}$ in tablet form. This research was conducted to determine the effect of storage temperature on the content of vitamin $\mathrm{C}$ in tablets sold in the market. In this research used two kinds of vitamin $\mathrm{C}$ tablet samples were obtained at random (random sampling). Samples were treated in the form of storage at cold temperatures $\left(5^{\circ} \mathrm{C}\right)$, room temperatures $\left(27^{\circ} \mathrm{C}\right)$ and overheating temperatures $\left(48^{\circ} \mathrm{C}\right)$ for 180 minutes with three repetitions and levels of vitamin $\mathrm{C}$ were measured using UV-Vis spectrophotometry. The highest content of vitamin $\mathrm{C}$ tablets found in tablets stored at cold temperatures $\left(5^{\circ} \mathrm{C}\right)$ with a percentage content of the sample $\mathrm{I}=100.6 \%$ and sample $\mathrm{II}=.101 .3 \%$. The lowest amount of vitamin $\mathrm{C}$ found in tablets stored at overheating temperatures $\left(48^{\circ} \mathrm{C}\right)$ with a percentage content of the sample $\mathrm{I}=91.2 \%$ and sample $\mathrm{II}=96.6 \%$. From the test results obtained results are not statistically significant difference from the samples I and II were stored at cold temperatures $\left(5^{\circ} \mathrm{C}\right)$ to room temperature $\left(27^{\circ} \mathrm{C}\right)$. While there are significant differences in the tablets stored at overheating temperatures $\left(48^{\circ} \mathrm{C}\right)$. Based on research that has been done can be concluded that storage temperature influential on the content of vitamin $\mathrm{C}$ tablets, wherein excess storage at temperatures may reduce levels of vitamin $\mathrm{C}$ on the tablet.
\end{abstract}

Keywords: Tablet Vitamin C, Vitamin C levels, Effect of Storage Temperature, UV-Vis spectrophotometry 


\section{PENDAHULUAN}

Mutu obat adalah semua unsur-unsur yang berpengaruh secara langsung maupun tidak langsung terhadap keamanan, keefektifan dan derajat diterimanya suatu produk obat. Mutu suatu obat atau kualitas produk obat sangat penting karena akan menentukan efek terapetik yang dihasilkan. Mutu suatu sediaan obat dapat ditinjau dari berbagai aspek, salah satunya aspek teknologi yang meliputi stabilitas fisik dan kimia, dimana sediaan obat seperti tablet dan bentuk sediaan lainnya harus memenuhi kriteria yang dipersyaratkan.

Suhu merupakan salah satu faktor luar yang menyebabkan ketidakstabilan obat. Hal ini memungkinkan peramalan stabilitas obat pada suhu kamar dan ekstrim, untuk mengetahui perubahan selama proses penyimpanan. Penyimpanan obat yang kurang baik merupakan salah satu masalah yang dapat mengganggu dalam upaya mempertahankan mutu obat. Salah satu contoh obat yang harus diperhatikan penyimpanannya adalah tablet vitamin C. Di samping sangat larut dalam air, vitamin $\mathrm{C}$ mudah teroksidasi dan dipercepat oleh panas, sinar, alkali, enzim, oksidator, serta oleh katalis tembaga dan besi. Oksidasi akan terhambat apabila vitamin $\mathrm{C}$ dibiarkan dalam keadaan asam, atau pada suhu rendah. Tablet vitamin $\mathrm{C}$ umumnya dikonsumsi oleh masyarakat sebagai suplemen antioksidan (Lestari, 2013). Walaupun vitamin C merupakan molekul yang labil, namun dalam bidang kefarmasian, saat ini vitamin $\mathrm{C}$ sintetik tersedia dalam berbagai variasi bentuk suplemen termasuk tablet, kapsul, tablet kunyah, serbuk kristalin, effervescent maupun dalam sediaan cair (Matei et al, 2008).

Asam askorbat merupakan komponen aktif dari tablet vitamin C. Asam askorbat tidak stabil bahkan pada suhu kamar dimana peningkatan suhu dan kelembaban dapat mempercepat proses degradasinya. Kecepatan degradasi dari asam askorbat yang tidak terlindungi umumnya meningkat dua kali lipat setiap peningkatan suhu $10^{\circ} \mathrm{C}$ (Pavlovska, 2011).

Pada kenyataanya, penyimpanan tablet vitamin $\mathrm{C}$ tidak selalu sesuai dengan anjuran penyimpanan karena kurangnya kontrol suhu baik di ruang penyimpanan maupun selama proses distribusi. Sifat yang tidak stabil dari vitamin C memerlukan teknologi formulasi khusus dalam proses produksi tablet vitamin C. Bentuk sediaan tablet vitamin $\mathrm{C}$ dituntut agar mampu mempertahankan stabilitas kandungan zat aktifnya dalam berbagai suhu penyimpanan. Dengan demikian perlu diketahui kemampuan sediaan tablet vitamin $\mathrm{C}$ yang beredar di pasaran dalam mempertahankan kandungan zat aktifnya selama penyimpanan pada berbagai suhu. Penelitian ini bertujuan untuk mengetahui pengaruh suhu penyimpanan baik dalam keadaan suhu kamar $\left(27^{\circ} \mathrm{C}\right)$, suhu rendah $\left(5^{\circ} \mathrm{C}\right)$, dan suhu panas berlebih $\left(48^{\circ} \mathrm{C}\right)$ terhadap kadar vitamin $\mathrm{C}$ pada tablet vitamin $\mathrm{C}$ yang ada di pasaran. Penentuan kadar dilakukan dengan menggunakan metode spektrofotometri $U V$-Vis dimana metode ini merupakan salah satu metode yang mudah dan cepat untuk menentukan kandungan asam askorbat.

\section{BAHAN DAN METODE}

Rancangan Penelitian. Penelitian ini dilakukan di laboratorium terpadu Akademi Farmasi Saraswati Denpasar, pada bulan Juni 2015. Penelitian ini menggunakan metode eksperimental dengan pendekatan kuantitatif dengan cara mengukur kadar asam askorbat dari sampel tablet vitamin $\mathrm{C}$ setelah disimpan pada suhu dingin $\left(5^{\circ} \mathrm{C}\right)$, suhu kamar $\left(27^{\circ} \mathrm{C}\right)$ dan suhu panas berlebih $\left(48^{\circ} \mathrm{C}\right)$ masing-masing selama 180 menit. Penelitian ini dilakukan untuk mengetahui apakah terdapat perbedaan kadar antara tablet vitamin C yang disimpan pada suhu $27^{\circ} \mathrm{C}$ dibandingkan dengan tablet vitamin $\mathrm{C}$ yang disimpan pada suhu $48^{\circ} \mathrm{C}$ dan suhu $5^{\circ} \mathrm{C}$.

Bahan. Bahan yang digunakan dalam penelitian ini yaitu, tablet vitamin C sampel I $(50 \mathrm{mg} / \mathrm{tab})$, tablet vitamin C sampel II (100 mg/tab) dan standar vitamin C (Brataco). Sampel yang digunakan diambil dari Apotek $\mathrm{X}$ yang ada di Kota Denpasar dengan menggunakan metode random sampling (sampel diambil secara acak).

\section{Metode}

A. Uji Organoleptik

Uji organoleptik tablet vitamin $\mathrm{C}$ dilakukan dengan mengamati bentuk, warna, dan bau.

\section{B. Penetapan Kadar}

1. Perlakuan Sampel

Sebanyak 20 tablet dari masing-masing sampel vitamin $\mathrm{C}$ yang telah memenuhi keseragaman bobot disimpan pada suhu rendah dengan lemari pendingin $\left(5^{\circ} \mathrm{C}\right)$, suhu kamar $\left(27^{\circ} \mathrm{C}\right)$ dan panas berlebih dengan menggunakan oven $\left(48^{\circ} \mathrm{C}\right)$ masing-masing selama 180 menit. Setelah 180 menit, seluruh sampel dikeluarkan dan dilanjutkan dengan pembuatan larutan sampel. 


\section{Pembuatan Larutan Sampel}

Dua puluh tablet vitamin C ditimbang untuk mengetahui bobot totalnya. Selanjutnya tablet digerus menggunakan mortir dan diambil serbuk yang setara dengan $50 \mathrm{mg}$ vitamin $\mathrm{C}$ kemudian dilarutkan dalam labu ukur $100 \mathrm{~mL}$ dengan akuades. Selanjutnya larutan disaring dan dilakukan pengenceran dalam labu ukur $100 \mathrm{~mL}$ dengan cara diambil sebanyak $2 \mathrm{~mL}$ kemudian ditambahkan akuades hingga tanda batas.

\section{Larutan Baku Pembanding}

Ditimbang sebanyak $50 \mathrm{mg}$ serbuk vitamin C (asam askorbat) standar kemudian dilarutkan dalam labu ukur $100 \mathrm{~mL}$ dengan akuades. Setelah itu, dilakukan pengenceran dalam labu ukur $100 \mathrm{~mL}$ dengan cara diambil 2 $\mathrm{mL}$ kemudian ditambahkan akuades hingga tanda batas. Selanjutnya dilakukan pengukuran absorban larutan menggunakan alat Spektrofotometer UV-Vis (Series UV-6 Spectrophotometer, Shanghai MAPADA Instruments Co., Ltd.) untuk menentukan panjang gelombang maksimumnya.

\section{Cara penetapan kadar sampel}

Serapan larutan sampel dan larutan standar diukur dengan menggunakan spektrofotometer $U V$-Vis pada panjang gelombang maksimal $266 \mathrm{~nm}$ dan digunakan akuades sebagai blanko. Penetapan kadar zat aktif sampel diukur tiga kali (triplo) dengan menggunakan rumus persamaan berikut (Depkes RI, 1979):

Kadar Sampel (\%):

$$
\frac{V u}{V b} \times \frac{F u}{F b} \times \frac{A u}{A b} \times \frac{B r}{B u} \times \frac{B b}{K e} \times 100 \%
$$

Keterangan:

a. $\mathrm{Vu} \quad$ : Volume larutan uji (mL)

b. $\mathrm{Vb}$ : Volume larutan baku $(\mathrm{mL})$

c. Fu : Faktor pengenceran larutan uji

d. $\mathrm{Fb}$ : Faktor pengenceran larutan baku

e. $\mathrm{Au} \quad$ : Absorbansi larutan uji

f. Ab : Absorbansi larutan baku

g. $\mathrm{Br}$ : Bobot rata-rata 1 tablet $(\mathrm{mg})$

$\mathrm{h} . \mathrm{Bu}$ : Bobot bahan uji yang digunakan (mg)

i. $\mathrm{Bb}$ : Bobot baku yang ditimbang

j. Ke : Kandungan vitamin $\mathrm{C}$ yang tertera pada etiket (mg)

\section{Metode Pengolahan Data}

Data yang diperoleh dari hasil pengujian kemudian dianalisa secara statistik dengan metode
One Way ANOVA menggunakan program SPSS for Windows untuk melihat apakah suhu penyimpanan berpengaruh signifikan terhadap kadar asam askorbat dalam tablet vitamin $\mathrm{C}$ yang dijual di pasaran, dengan taraf kepercayaan $95 \%$, dan jika ada perbedaan nyata dilanjutkan dengan uji Post Hoc.

\section{HASIL DAN PEMBAHASAN}

\section{Hasil Uji Organoleptik}

1. Tablet Vitamin C sampel I

Tablet vitamin $\mathrm{C}$ yang digunakan:
a) Pabrik
: PT. X
b) Kandungan di etiket
: $50 \mathrm{mg}$
c) Kemasan sediaan : botol berwarna bening

Hasil Pengamatan :
a) Warna tablet
: kuning terang
b) Bau tablet
: tidak berbau

2. Tablet Vitamin C sampel II

Tablet vitamin $\mathrm{C}$ yang digunakan:
a) Pabrik
: PT. Y
b) Kandungan di etiket : $100 \mathrm{mg}$
c) Kemasan sediaan : kotak berwarna putih

Hasil Pengamatan :
a) Warna tablet
b) Bau tablet
: putih bersih
: tidak berbau

Tabel 1. Hasil Absorbansi Sampel dan Standar Vitamin $C\left(\lambda_{\max }=266 \mathrm{~nm}\right)$

\begin{tabular}{|c|c|c|c|c|c|c|}
\hline \multirow[t]{2}{*}{ No } & \multirow[t]{2}{*}{$\begin{array}{c}\text { Nama } \\
\text { Sampel }\end{array}$} & \multirow{2}{*}{$\begin{array}{l}\text { Suhu } \\
\text { Penyim } \\
\text { panan }\end{array}$} & \multicolumn{3}{|c|}{$\begin{array}{c}\text { Absorbansi } \\
\text { Pada Masing-Masing } \\
\text { Pengukuran }\end{array}$} & \multirow[t]{2}{*}{$\begin{array}{c}\text { Rata- } \\
\text { rata }\end{array}$} \\
\hline & & & 1 & 2 & 3 & \\
\hline \multirow{3}{*}{1} & \multirow{3}{*}{$\begin{array}{l}\text { Tablet } \\
\text { Vit.C } \\
\text { I }\end{array}$} & $5^{\circ} \mathrm{C}$ & 0,825 & 0,842 & 0,841 & 0,836 \\
\hline & & $27^{\circ} \mathrm{C}$ & 0,866 & 0,824 & 0,783 & 0,824 \\
\hline & & $48^{\circ} \mathrm{C}$ & 0,761 & 0,757 & 0,755 & 0,757 \\
\hline \multirow{3}{*}{2} & \multirow{3}{*}{$\begin{array}{l}\text { Tablet } \\
\text { Vit.C } \\
\text { II }\end{array}$} & $5^{\circ} \mathrm{C}$ & 0,847 & 0,837 & 0,842 & 0,842 \\
\hline & & $27^{\circ} \mathrm{C}$ & 0,883 & 0,843 & 0,838 & 0,854 \\
\hline & & $48^{\circ} \mathrm{C}$ & 0,797 & 0,806 & 0,806 & 0,803 \\
\hline 3 & $\begin{array}{c}\text { Standar } \\
\text { Vit.C }\end{array}$ & $27^{\circ} \mathrm{C}$ & 0,830 & 0,830 & 0,831 & 0,830 \\
\hline
\end{tabular}

Dari hasil absorban yang diukur dengan menggunakan panjang gelombang maksimum vitamin C (266 nm) dengan metode spektrofotometri UV-Vis, didapatkan hasil absorbansi yang digunakan untuk menghitung kadar vitamin C. Kadar vitamin C pada sampel dapat dilihat pada tabel 2. 
Tabel 2. Hasil Perhitungan Kadar Sampel

\begin{tabular}{|c|c|c|c|c|c|c|}
\hline \multirow[t]{2}{*}{ No } & \multirow[t]{2}{*}{ Sampel } & \multirow[t]{2}{*}{ Suhu } & \multicolumn{3}{|c|}{$\begin{array}{c}\text { Kadar (\%) pada } \\
\text { Masing-Masing } \\
\text { Pengukuran }\end{array}$} & \multirow[t]{2}{*}{$\begin{array}{l}\text { Rata-rata } \pm \\
\text { Std. Deviasi }\end{array}$} \\
\hline & & & 1 & 2 & 3 & \\
\hline \multirow{3}{*}{1} & \multirow{3}{*}{$\begin{array}{l}\text { Tablet } \\
\text { Vit.C } \\
\text { I }\end{array}$} & $5^{\circ} \mathrm{C}$ & 99,3 & 101,4 & 101,2 & $100,6 \% \pm 1,16$ \\
\hline & & $27^{\circ} \mathrm{C}$ & 104,3 & 99,2 & 94,2 & $99,2 \% \pm 5,05$ \\
\hline & & $48^{\circ} \mathrm{C}$ & 91,6 & 91,2 & 90,8 & $91,2 \% \pm 0,40$ \\
\hline \multirow{3}{*}{2} & \multirow{3}{*}{$\begin{array}{c}\text { Tablet } \\
\text { Vit.C } \\
\text { II }\end{array}$} & $5^{\circ} \mathrm{C}$ & 102 & 100,8 & 101,3 & $101,3 \% \pm 0,60$ \\
\hline & & $27^{\circ} \mathrm{C}$ & 106,3 & 101,5 & 100,8 & $102,8 \% \pm 2,99$ \\
\hline & & $48^{\circ} \mathrm{C}$ & 96 & 97,1 & 96,9 & $96,6 \% \pm 0,59$ \\
\hline 3 & $\begin{array}{c}\text { Standar } \\
\text { Vit.C }\end{array}$ & $27^{\circ} \mathrm{C}$ & 100 & 100 & 100 & $100 \% \pm 0.00$ \\
\hline
\end{tabular}

\section{Pembahasan}

Penelitian ini bertujuan untuk mengetahui apakah suhu penyimpanan tablet vitamin $\mathrm{C}$ yang ada di pasaran berpengaruh pada stabilitas kandungan aktifnya. Sifat vitamin $\mathrm{C}$ yang tidak stabil memerlukan bentuk sediaan dan formulasi yang mampu mempertahankan stabilitas kandungan aktifnya sehingga dapat mempertahankan mutu sediaan selama proses penyimpanan dan distribusi.

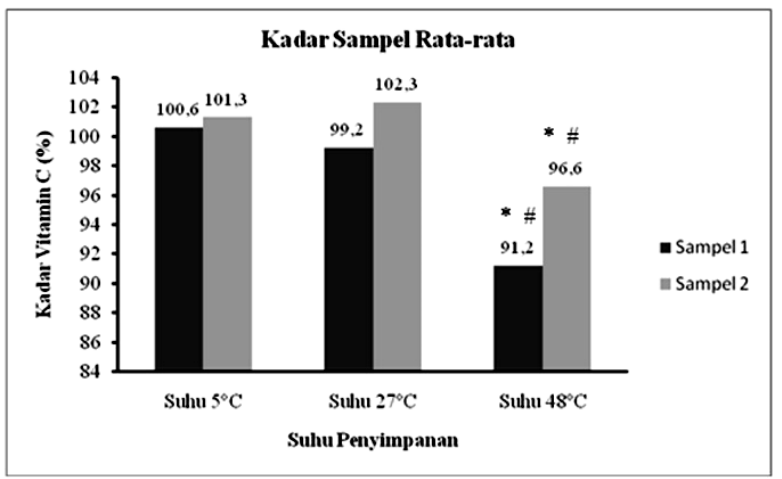

Gambar 1. Diagram Kadar Sampel Rata-rata

Keterangan:

*: $\mathrm{p}<0,05$ dibandingkan dengan suhu $5^{\circ} \mathrm{C}$.

\#: $\mathrm{p}<0,05$ dibandingkan dengan suhu $27^{\circ} \mathrm{C}$.

Pada penelitian ini diberikan tiga perlakuan suhu penyimpanan terhadap tablet vitamin $\mathrm{C}$ yaitu yang disimpan pada suhu dingin dengan lemari pendingin $\left(5^{\circ} \mathrm{C}\right)$, suhu kamar $\left(27^{\circ} \mathrm{C}\right)$ dan suhu panas berlebih $\left(48^{\circ} \mathrm{C}\right)$ yang mungkin terjadi selama penyimpanan maupun pendistribusian misalnya pada penyimpanan yang terpapar oleh panas matahari. Setelah dilakukan pengukuran kadar asam askorbat dalam tablet vitamin C pada berbagai suhu penyimpanan, terlihat adanya perbedaan kadar vitamin $\mathrm{C}$ pada masing-masing sampel, untuk mengetahui apakah ada perbedaan yang signifikan antar kelompok perlakuan, data diolah secara statistik.

Setelah dilakukan uji statistik One Way ANOVA terhadap hasil kadar tablet vitamin C sampel I dan II, diperoleh nilai signifikansi (p) pada data kadar sampel $\mathrm{I}=0,017(\mathrm{p}<0,05)$ dan sampel II =0,013 ( $<<0,05)$. Dari hasil uji One Way ANOVA tersebut menunjukan bahwa ada perbedaan kadar yang signifikan pada tablet vitamin $\mathrm{C}$ sampel I dan II yang disimpan pada suhu $5^{\circ} \mathrm{C}, \quad 27^{\circ} \mathrm{C}$ dan $48^{\circ} \mathrm{C}$. Hal tersebut menunjukkan bahwa suhu penyimpanan berpengaruh signifikan terhadap kadar asam askorbat dalam tablet vitamin C. Setelah dilakukan uji statistik One Way ANOVA dilanjutkan dengan melakukan uji Post Hoc untuk menentukan kelompok perlakuan yang memiliki perbedaan kadar yang signifikan, dan diperoleh hasil bahwa tidak terdapat perbedaan kadar yang bermakna pada tablet vitamin $\mathrm{C}$ sampel I dan II yang disimpan pada suhu dingin $\left(5^{\circ} \mathrm{C}\right)$ dengan suhu kamar $\left(27^{\circ} \mathrm{C}\right)(\mathrm{p}>0,05)$. Sedangkan terdapat perbedaan kadar yang signifikan dari kadar vitamin $\mathrm{C}$ pada tablet yang disimpan pada suhu panas berlebih $\left(48^{\circ} \mathrm{C}\right)$ dengan yang disimpan pada suhu dingin $\left(5^{\circ} \mathrm{C}\right)$ dan suhu kamar $\left(27^{\circ} \mathrm{C}\right)$, seperti yang terlihat pada gambar 1 . Artinya suhu panas berpengaruh signifikan terhadap penurunan kadar asam askorbat dalam sampel tablet vitamin $\mathrm{C}$. Hasil penelitian ini sejalan dengan hasil penelitian yang dilakukan oleh Pavlovska dan Tanevska pada tahun 2011 yang menguji pengaruh suhu dan kelembaban terhadap proses degradasi asam askorbat dalam tablet kunyah vitamin $\mathrm{C}$ yang disimpan pada suhu kamar $25^{\circ} \mathrm{C}$, serta suhu panas $30^{\circ} \mathrm{C}$ dan $40^{\circ} \mathrm{C}$ dengan kelembaban tertentu. dimana diperoleh hasil bahwa degradasi asam askorbat paling cepat terjadi pada tablet yang disimpan pada suhu $40^{\circ} \mathrm{C}$ dibandingkan dengan yang disimpan pada suhu kamar. Dengan demikian, dapat diketahui bahwa peningkatan suhu dapat mempercepat proses degradasi asam askorbat dalam sediaan tablet vitamin $\mathrm{C}$ sehingga pembuatan tablet vitamin $\mathrm{C}$ harus memperhatikan ketangguhan formulasi tablet vitamin $\mathrm{C}$ dalam mempertahankan kestabilan zat aktifnya dalam berbagai kemungkinan suhu penyimpanan termasuk pada suhu berlebih. Namun, perlu diperhatikan bahwa dalam penelitian ini tidak dilakukan control terhadap kelembaban pada proses perlakukan selama penyimpanan pada suhu yang ditentukan. 


\section{SIMPULAN}

Berdasarkan hasil penelitian yang telah dilakukan dapat disimpulkan bahwah suhu berpengaruh nyata terhadap kandungan asam askorbat dalam sediaan tablet vitamin $\mathrm{C}$ yang ada dipasaran, dimana diperoleh hasil kadar tablet vitamin $\mathrm{C}$ berturut-turut adalah, pada sampel I yang disimpan pada suhu dingin $\left(5^{\circ} \mathrm{C}\right) 100,6 \%$, suhu kamar $\left(27^{\circ} \mathrm{C}\right) \quad 99,2 \%$ dan suhu panas berlebih $\left(48^{\circ} \mathrm{C}\right) 91,2 \%$. Sedangkan kadar vitamin C sampel II yang disimpan pada suhu dingin $\left(5^{\circ} \mathrm{C}\right) 101,3 \%$, suhu kamar $\left(27^{\circ} \mathrm{C}\right) 102,8 \%$ dan suhu panas berlebih $\left(48^{\circ} \mathrm{C}\right) 96,6 \%$. Pengukuran kadar dilakukan setelah 180 menit penyimpanan pada suhu tersebut.

Hasil uji statistik ANOVA menunjukkan bahwa tidak ada perbedaan kadar tablet vitamin C sampel I dan II yang disimpan pada suhu dingin $\left(5^{\circ} \mathrm{C}\right)$ dengan suhu kamar $\left(27^{\circ} \mathrm{C}\right)$, sedangkan terdapat perbedaan yang signifikan antara kadar vitamin $\mathrm{C}$ yang disimpan pada suhu panas berlebih $\left(48^{\circ} \mathrm{C}\right)$.

\section{DAFTAR PUSTAKA}

Depkes RI, 1979, Farmakope Indonesia, Edisi III, Departemen Kesehatan Republik Indonesia, Jakarta.

Lestari N, 2013, Pengaruh Kondisi Penyimpanan Obat Terhadap Kualitas Tablet Vitamin C di Puskesmas Kecamatan Pontianak Kota, Skripsi dipublikasikan, Pontianak, Fakultas Kedokteran Universitas Tanjungpura.

Matei et al, 2008, Kinetic Study of Vitamin C degradation from Pharmaceutical Products, Rom. Journ. Phys., Vol. 53, P. 343-351.

Pavlovska, G. \& S. Tanevska, 2011, Influence of Temperature and Humidity on The Degradation Process of Ascorbic Acid in Vitamin C Chewable Tablets, J Therm Anal Calorim DOI 10.1007/s10973-011-2151-z. 